\title{
Characteristics of immunocompetent cells in synovial membranes from multiple sites in patients with rheumatoid arthritis
}

\author{
J G Hanly, D Pledger
}

\begin{abstract}
The phenotypic characteristics of enzymatically dissociated mononuclear cells in synovial membrane samples from multiple sites in two patients with rheumatoid arthritis (RA) were examined by fluorescence activated flow cytometry. In synovial membrane samples from each patient there was a consistent increase in the proportion of $\mathrm{CD8}+$ cells (suppressor/cytotoxic), CD14+ cells (monocytes/macrophages), and HLA-DR+ cells compared with paired peripheral blood mononuclear cells. The proportion of CD4+ cells (helper/inducer) in synovial membrane was variable. Studies of in vitro production of IgM and IgM rheumatoid factor in one patient showed strikingly similar values for synovial membrane rheumatoid factor production at the two sites, which was enhanced compared with production in peripheral blood. These results suggest that in individual patients with RA the intra-articular immune response is comparable at multiple anatomical sites and that it is distinct frcm that in peripheral blood.
\end{abstract}

(Ann Rheum Dis 1992; 51: 1066-1068)

One of the hallmarks of rheumatoid arthritis (RA) is the presence of a symmetric peripheral polyarthritis which tends to fluctuate uniformly with changes in overall disease activity. The pathological basis of this clinical observation is rheumatoid synovitis which is characterised by a brisk infiltrate of mononuclear cells, predominantly $\mathrm{T}$ lymphocytes, and an enhanced production of cytokines, immunoglobulins, and rheumatoid factors. ${ }^{1-10}$ Although the immunopathological features of rheumatoid synovitis have been studied in detail in tissue samples retrieved from single anatomical sites there is little information available on the characteristics of the intra-articular immune response in synovial membrane samples from multiple sites in individual patients at a single point in time. Such information would allow an appreciation of potential regional variability of the immune response at different disease sites and help to determine how well the findings at one site reflect the immunopathological events elsewhere. In this paper we describe the phenotypic characteristics of mononuclear cells isolated by enzymatic dissociation of synovial membrane samples from multiple sites in two patients with RA and spontaneous production of IgM and IgM rheumatoid factor in one patient.

\section{Case reports}

Synovial membranes were obtained from two patients with RA during the course of elective surgery. Patient A underwent synovectomies of the tendon sheaths of the finger flexors and wrist extensors of the right and left hands one week apart and patient $B$ had joint arthroplasties of the second, third, and fourth metacarpophalangeal joints of the left hand. At the time of study the two patients had active disease, including at the sites from which synovial membrane samples were obtained. Both patients had circulating rheumatoid factor (latex fixation test) and patient $B$ had radiological evidence of erosive joint disease. Both were receiving enteric coated aspirin and patient $A$ was also receiving chloroquine and patient $B$ azathioprine.

Synovial membrane mononuclear cells were retrieved by enzymatic dissociation with collagenase and DNAase as previously described. ${ }^{11}$ The cell yield varied between 2.04 and $15.8 \times 10^{6}$ and viability, as assessed by trypan blue exclusion, was between 81 and $94 \%$. Peripheral blood mononuclear cells were isolated from heparinised venous blood by Ficoll-Paque (Pharmacia, Uppsala, Sweden) density centrifugation. The phenotypic characteristics of dissociated synovial membrane cells and peripheral blood mononuclear cells were examined by fluorescence activated flow cytometry as previously described ${ }^{11}$ using a panel of monoclonal antibodies: anti-Leu 1 (CD5) (T lymphocytes), anti-Leu 3a (CD4) (helper/inducer T lymphocytes), anti-Leu2a (CD8) (suppressor/ cytotoxic T lymphocytes), anti-Leu M3 (CD14) (monocytes/macrophages), and anti-HLA-DR (Becton Dickinson, Mountain View, CA, USA). To facilitate the comparison of cell populations isolated from peripheral blood and synovial membrane, $\mathrm{CD} 4+$ and $\mathrm{CD} 8+$ cells were expressed as a percentage of CD5+ cells. To determine the in vitro production of total $\operatorname{IgM}$ and IgM rheumatoid factor, isolated synovial membrane and peripheral blood mononuclear cells were cultured in RPMI medium with $10 \%$ fetal calf serum and antibiotics in microtitre wells at a concentration of $1 \times 10^{5} /$ well. Following a seven day culture the supernatants were harvested and the levels of $\operatorname{IgM}$ and $\operatorname{IgM}$ rheumatoid factor determined by enzyme linked immunosorbent assay (ELISA) as previously described. ${ }^{12}$

Analysis of $\mathrm{T}$ lymphocyte cell populations (table) showed that the two patients had markedly decreased percentages of peripheral blood CD8 + cells (normal mean (SD) in our laboratory $25(2 \cdot 4))$ which was responsible for the high CD4:CD8 ratios in peripheral blood. In contrast, the percentage of $\mathrm{CD} 8+$ cells in synovial membrane samples from the two 
Phenotypic characteristics and IgM and IgM rheumatoid factor $(R F)$ production in peripheral blood $(P B)$ and synovial membrane $(S M)$ from patients with rheumatoid arthritis

\begin{tabular}{|c|c|c|c|c|c|c|c|c|c|}
\hline & \multicolumn{5}{|c|}{ Patient A } & \multicolumn{4}{|c|}{ Patient B } \\
\hline & $P B$ & $S M 1$ & SM2 & $S M 3$ & SM4 & $P B$ & $S M I$ & $S M 2$ & $S M 3$ \\
\hline $\begin{array}{l}\text { CD4+ (\%) } \\
\text { CD8+ (\%) } \\
\text { CD4+:CD8+ } \\
\text { CD14+ (\%) } \\
\text { HLA-DR+ (\%) } \\
\text { IgM* } \\
\text { IgM RF* }\end{array}$ & $\begin{array}{l}50 \\
7.9 \\
6 \cdot 3 \\
6 \cdot 1 \\
1 \cdot 1 \\
1.43 \\
1.37\end{array}$ & $\begin{array}{l}36 \\
36 \\
1 \cdot 0 \\
\frac{25}{-}\end{array}$ & $\begin{array}{l}74 \\
26 \\
2 \cdot 9 \\
25 \\
15 \\
- \\
-\end{array}$ & $\begin{array}{l}49 \\
18 \\
2 \cdot 7 \\
29 \\
30 \\
0.60 \\
1 \cdot 43\end{array}$ & $\begin{array}{l}79 \\
38 \\
28 \\
27 \\
37 \\
44 \\
0 \cdot 39 \\
1 \cdot 45\end{array}$ & $\begin{array}{l}58 \\
7 \cdot 5 \\
7 \cdot 7 \\
-7 \cdot 3 \\
- \\
-\end{array}$ & $\begin{array}{l}55 \\
28 \\
2 \cdot 0 \\
= \\
= \\
-\end{array}$ & $\begin{array}{l}60 \\
40 \\
1 \cdot 5 \\
= \\
= \\
=\end{array}$ & $\begin{array}{l}95 \\
24 \\
4 \cdot 0 \\
= \\
= \\
-\end{array}$ \\
\hline
\end{tabular}

${ }^{*}$ Absorbance units.

patients was higher than the percentage in paired peripheral blood samples. The proportion of CD4+ cells in synovial membrane samples was variable and there was no consistent relation with the proportion of CD4+ cells in peripheral blood. Thus the CD4:CD8 ratio in synovial membrane fell between 1.0 and 3.0 in six of seven patients. The proportions of CD14+ cells and HLA-DR+ cells were substantially higher in all synovial membrane samples compared with peripheral blood. The in vitro production of IgM and IgM rheumatoid factor showed almost identical values for the two synovial membrane samples studied. There was a selective enrichment for rheumatoid factor production in synovial membrane samples compared with peripheral blood (table).

\section{Discussion}

The phenotypic characteristics of the mononúclear cell infiltrate in synovial membrane from patients with RA has usually been examined by immunohistological studies. ${ }^{6-10}$ We have taken an alternative approach by examining enzymatically dissociated cells from synovial membrane which yields complementary information and, in particular, facilitates the assessment of the constituents of the total infiltrate. Owing to ethical considerations and the difficulty in obtaining sufficient tissue for analysis there have been no studies comparing the phenotypic characteristics of the infiltrate in several synovial membrane sites concurrently in individual patients. In this study, although the number of samples was limited, the phenotypic characteristics of the synovial membrane infiltrates suggest a comparable immune response at multiple peripheral sites in individual patients. This is supported by the similarity in the in vitro production of IgM and, in particular, IgM rheumatoid factor production by dissociated synovial membrane cells in the two samples studied. Thus identification of immunopathogenic events in synovial membrane samples from a single site in individual patients with $R A$ probably reflects a similar process at other anatomical sites of disease.

Several studies have examined the phenotypic characteristics of lymphocytes in the circulation and within the synovial membrane in patients

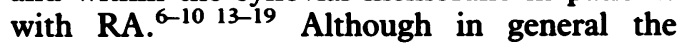
proportions of CD4t and CD8+ cells in peripheral blood have been similar to those found in normal subjects, some studies ${ }^{14} 15$ have reported a significant reduction in the percentage of CD8 + cells which is most apparent in patients with active disease. ${ }^{14}$ As in the two patients reported here this has not always been accompanied by a compensatory increase in the proportion of CD4+ cells. ${ }^{14}$ Immunohistological studies of synovial membrane have highlighted the regional predominance of $\mathrm{CD} 4+$ cells. $^{6-10}$ $W^{11}$ and others ${ }^{20}{ }^{21}$, however, have shown that when dissociated synovial membrane preparations are examined this excess of CD4+ cells is not as striking. CD4+ cells have been proposed to promote $B$ cell hyperactivity within the synovial membrane. ${ }^{6-10}$ In the synovial membrane of patients with RA, however, it is CD8 + cells which bear more of the morphological appearances of cell activation and which are in closest anatomical association with resident $\mathrm{B}$ cells. ${ }^{8}$ Furthermore in studies of CD8+ cells from normal subjects ${ }^{22-24}$ and patients with systemic lupus erythematosus ${ }^{25}$ it has been shown that they may promote rather than suppress B cell proliferation and autoantibody production. Therefore the finding of increased proportions of CD8 + cells in synovial membrane compared with paired peripheral blood samples may indicate an important role for this lymphocyte population in the intraarticular immune response in RA.

The differences in phenotypic characteristics between synovial membrane and paired peripheral blood samples suggest a selective recruitment rather than a passive transfer of immunocompetent cells into the joint lining. Most CD4+ and CD8+ cells in synovial membrane from patients with RA are memory cells and express the surface antigen CDw29. ${ }^{11} 21$ This molecule belongs to a group of conserved adhesive receptors called integrins ${ }^{26} 27$ which mediate cell-cell and cell-matrix interactions and play a pivotal part in cell trafficking and localisation. Thus the entry and subsequent localisation of immunocompetent cells within the joint cavity in RA is likely to be facilitated by the expression of CDw29.

We thank Dr Winston Parkhill and Dr Michael Roberts for providing synovial membrane samples and Joan Embree for her assistance in performing flow cytometry. Supported by a grant from the Dalhousie University Internal Medicine Research Foundation. Dr Hanly is a Clinical Associate of the Canadian Arthritis Society.

1 Zvaifler N J. Etiology and pathogenesis of rheumatoid arthritis. In: McCarty D J, ed. Arthritis and allied conditions. Philadelphia: Lea and Febiger, 1985: 557-76.

2 Krane S M. Mechanisms of tissue destruction in rheumatoid arthritis. In: McCarty D J, ed. Arthritis and allied conditions. Philadelphia: Lea and Febiger, 1985: 593-604.

3 Firestein G S, Zvaifler N J. The pathogenesis of rheumatoid arthritis: a critical assessment of the role of autologous stimulation in the perpetuation of rheumatoid synovitis. Rherom Dis Clin North Am 1987; 13: 447-61.

4 Maini R N, Plater-Zyberk C, Andrew E. Autoimmunity in theumatoid arthritis: an approach via a study of $B$ lymphocytes. Rherm Dis Clin North Am 1987; 13: 319-38.

Wernick R M, Lipsky P E, Marban-Arcos E, Maliakkal J J Edelbaum D, Ziff $M$. IgG and IgM rheumatoid factor synthesis in rheumatoid synovial membrane cell cultures. Arthritis Rhewm 1985; 28: 742-52.

6 Janossy G, Duke O, Poulter L W, Panayi G, Bofill M, Goldstein G. Rheumatoid arthritis: a disease of T lymphocyte/macrophage immunoregulation. Lancet 1981; ii: 839-42.

7 Duke O, Panayi G S, Janossy G, Poulter L W. An immunohistological analysis of lymphocyte subpopulations in the synovial membranes of patients with rheumatoid arthritis using monoclonal antibodies. Clin Exp Immuno 1982; 49: 22-30.

8 Kurosaka $M$, Ziff $M$. Immunoelectron microscopic study of the distribution of $\mathrm{T}$ cell subsets in rheumatoid synovium. $\mathcal{F}$ Exp Med 1983; 158: 1191-210. 
9 Meijer C J L M, de Graaff C B, Lafeber G J M, Cats A. In situ localization of lymphocyte subsets in synovial membranes of patients with rheumatoid arthritis with monoclonal antibodies. I Rheumatol 1982; 9: 359-65.

10 Malone D G, Wahl S M, Tsokos M, Cattell H, Decker J L, Wilder R L. Immune function in severe, active rheumatoid arthritis. $\mathcal{F}$ Clin Invest 1984; 74: 1173-85.

11 Hanly J G, Pledger D, Parkhill W, Roberts M, Gross M. Phenotypic characteristics of dissociated mononuclear cells from rheumatoid synovial membrane. $\mathcal{f}$ Rheumatol 1990; 17: $1274-9$.

12 Hanly J G, Hassan J, Whelan A, Feighery C, Bresnihan B. Effects of gold therapy on synthesis and quantity of serum and synovial IgM, IgG, and IgA rheumatoid factors in rheumatoid arthritis patients. Arthritis Rheum 1986; 29: 480-7.

13 Fox R I, Fong S, Sabharwal N, Carstens S A, Kung P C, Vaughan J H. Synovial fluid lymphocytes differ from peripheral blood lymphocytes in patients with rheumatoid arthritis. F Immunol 1982; 128: 351-4.

14 Duke O, Panayi G S, Janossy G, Poulter L W, Tidman N. Analysis of $T$ cell subsets in the peripheral blood and synovial fluid of patients with rheumatoid arthritis by means of monoclonal antibodies. Ann Rheum Dis 1983; 42: m57-61.

15 Veys E M, Hermanns P, Verbruggen G, Schindler J, Goldstein G. Evaluation of $T$ cell subsets with monoclonal antibodies in synovial fluid in rheumatoid arthritis. ҰR Reumatol 1982; 9: 821-6.

16 Melendro E I, Saldate C, Rivero S J, Alarcon-Segovia D. $T$-cell subpopulations in the peripheral blood of patients with connective tissue diseases as determined by flow with connective tissue diseases as determined by flow
cytometry using monoclonal antibodies. Clin Immunol cytometry using monoclonal

17 Bertouch J V, Roberts-Thompson P J, Brooks P M, Bradley J. Lymphocyte subsets and inflammatory indices in synovial fluid and blood of patients with rheumatoid arthritis. F Rheumatol 1984; 11: 754-9.
18 Luyten F, Suykens S, Veys E M, et al. Peripheral blood T lymphocyte subpopulations determined by monoclonal antibodies in active rheumatoid arthritis. $\mathcal{F}$ : Rheumatol 1986; 13: 864-9.

19 Goto M, Miyamoto T, Nishioka K, Okumura K. Selective loss of suppressor $\mathrm{T}$ cells in rheumatoid arthritis patients: analysis of peripheral blood lymphocytes by 2-dimensional flow cytometry. F R heumatol 1986; 13: 853-7.

20 Cush J J,. Lipsky P E. Phenotypic analysis of synovial tissue and peripheral blood lymphocytes isolated from patients and peripheral blood lymphocytes isolated from patients
with rheumatoid arthritis. Arthritis Rheum $1988 ; 31$ : $1230-8$.

21 Nakao H, Eguchi K, Kawakami A, et al. Phenotypic characteristics of lymphocytes infiltrating synovial tissue from patients with rheumatoid arthritis: analysis of lymphocytes isolated from minced synovial tissue by dual immunofluorescence staining. F R heumatol 1990; 17: 142-8.

22 Elmasry M N, Fox E J, Rich R R. Sequential effects of prostaglandins and interferon on differentiation of CD8+ suppressor cells. $\mathcal{F}$ Immunol 1987; 139: 688-94.

23 Thomas Y, Rogozinski L, Rabbani L, et al. Functional analysis of human $\mathrm{T}$ cell subsets defined by monoclonal antibodies. VI. Distinct and opposing immunoregulatory functions within the OKT8+ population. $\mathcal{f}$ Mol Cell Immunol 1984; 1: 103-10.

24 Hirohata S, Jelinek D F, Lipsky P E. T cell dependent activation of $B$ cell proliferation and differentiation by immobilized monoclonal antibodies to CD3. 7 Immunol 1988; 140: 3736-44.

25 Linker-Israeli M, Quismorio F P, Horwitz D A. CD8+ lymphocytes from patients with systemic lupus erythematosus sustain, rather than suppress, spontaneous polyclonal IgG production and synergize with CD4+ cells to support autoantibody synthesis. Arthritis Rheum 1990; 33: 1216-25.

26 Hynes R O. Integrins: a family of cell surface receptors. Cell 1987; 48: 549-54.

27 Hemler M E. Adhesive protein receptors on hematopoietic cells. Immunol Today 1988; 9: 109-13. 